\title{
Manajemen Paradigma dan Perilaku: Upaya Bergerak Menuju Kemajuan Pelaksanaan Program Green Campus
}

\author{
Raditia Yoke Pratama, Shintia Nur Kartini dan Danisa Kusuma Mardani \\ Universitas Sebelas Maret \\ raditiayoke@gmail.com
}

\begin{abstract}
Abstrak
Penelitian ini bertujuan untuk mengetahui pentingnya manajemen paradigma dan perilaku sebagai upaya gerakan menuju kemajuan pelaksanaan program green campus. Penelitian ini menggunakan metode penelitian deskriptif kualitatif dengan menggunakan data primer dan sekunder. Subyek dalam penelitian ini yaitu tim pelaksana pemeringkatan UI Green Metric World University Ranking Universitas Sebelas Maret (UNS) Tahun 2020. Pengumpulan data dilakukan dengan metode wawancara, Focus Group Discussion (FGD), observasi dan studi dokumentasi. Hasil dari penelitian ini mencakup: (1) paradigma biosentris dan deep ecology menjadi paradigma yang diperlukan guna mendorong kemajuan program green campus, (2) melalui model theory of planned behavior, manajemen perilaku menjadi penting dalam kemajuan program green campus, (3) kesuksesan program green campus terletak pada penyusunan strategi yang dikaitkan dan dikaji dengan paradigma lingkungan, faktor perilaku masyarakat, serta kemampuan sumber daya yang ada di Perguruan Tinggi.
\end{abstract}

Kata Kunci: Manajemen Paradigma, Perilaku, Green Campus

\section{Abstract}

The research is aimed at knowing the importance of paradigm management and behavior as a movement toward the implementation of the green campus program. The study uses qualitative descriptive research methods using primary and secondary data. The subject of this research is the UI GreenMatric World University Team Sebelas Maret University (UNS) 2020. Data collection is conducted by interview methods, focus group discussion (FGD), observation and documentary study. The results of this study includes: (1) the biocentric and deep ecology paradigms is a necessary paradigm to promote the progress of the green campus program, (2) through a model theory of planned behavior, the management of the green campus is also important for the development of the green campus program, (3) the success of the green campus program lies in formulating a strategy linked and studied with environmental paradigms, societal behavior factors, and collegiate resource capabilities.

Keywords: Paradigm Management, Behavior, Green Campus

\section{Pendahuluan}

Seiring dengan kompleksnya permasalahan lingkungan yang dihadapi oleh dunia ini, berbagai program perlindungan dan pelestarian lingkungan hidup telah dilakukan oleh pemangku kebijakan di Indonesia spesifik di wilayah pemerintahan, perguruan tinggi, sekolah, pesantren, hingga lembaga swadaya masyarakat. Bentuk permasalahan yang kini dihadapi mengenai lingkungan seperti semakin menipisnya sumberdaya alam tak terbaharui, meningkatnya emisi gas rumah kaca, pencemaran air dan udara, penurunan daya dukung dan daya tampung lingkungan, banjir, longsor, kekeringan, sampai degradasi keanekaragaman hayati.

Manajemen Paradigma dan Perilaku: Upaya Bergerak Menuju Kemajuan Pelaksanaan Program Green Campus | Raditia Yoke Pratama, Shintia Nur Kartini dan Danisa Kusuma 
Hasil perhitungan U.S Energy Information Administration (EIA) tahun 2018 menunjukkan bahwa konsumsi energi terbesar di dunia yaitu penggunaan energi fosil terutama minyak bumi. Sedangkan di Indonesia sendiri, konsumsi energi terbagi di sektor industri sebesar $36 \%$, transportasi $40 \%$, rumah tangga $16 \%$ serta sektor lain sebesar 8\% (ESDM, 2019).

Di Indonesia, Kementerian Lingkungan Hidup dan Badan Lingkungan Hidup Daerah telah memulai berbagai program perlindungan dan pelestarian lingkungan hidup. Lebih jauh dari itu, program sejenis juga sudah mulai digalakkan oleh LSM Lingkungan, sekolahsekolah, perguruan tinggi, dan pesantren. Selain program, ada kampanye, penyuluhan, sosialisasi, maupun kegiatan fisik langsung lainnya. Salah satu dari unit yang harus ikut dalam gerakan ini adalah kampus dimana di dalamnya berisi masyarakat ilmiah yang diharapkan lebih aktif lagi sebagai pelopor kegiatan tersebut. Kampus hijau atau green campus adalah istilah yang diciptakan untuk sebuah program bagi perguruan tinggi untuk lebih menaruh perhatian terhadap lingkungan hidup.

Program green campus ini
dilatarbelakangi karena adanya upaya
untuk mewujudkan lingkungan kampus
yang sehat, bersih, nyaman, teduh, indah,
dan aman untuk menimba ilmu
pengetahuan. Lebih dari itu, tidak kalah
penting bahwa bagaimana mewujudkan

warga kampus yang dapat mengimplementasikan IPTEK bidang lingkungan hidup secara nyata di lingkungan kampus serta masyarakat secara luas.

Salah satu perguruan tinggi yang masuk di antara 6 (enam) universitas di Indonesia sebagai pilot project penerapan green campus di Indonesia adalah Universitas Sebelas Maret (UNS). Enam universitas pilihan tersebut masuk di bawah pembinaan Kementerian Lingkungan Hidup yang nantinya akan diikuti oleh universitas lain. Kondisi masih barunya program green campus ini menunjukkan perlunya kerja keras yang lebih untuk menyukseskan tujuan ini.

Kesuksesan program ini ditunjang oleh banyak faktor, namun yang menjadi faktor utama adalah peran pimpinan perguruan tinggi, terutama di bidang pengembangan rencana strategis green campus. Perlunya komitmen dan konsistensi dalam mewujudkan program tersebut. Di lain sisi, dinamika performa pelaksanaan program ini tidak bisa dihindari, ada kekurangan dan kelebihan yang terjadi. Dalam hal ini, UNS berhasil mencapai target yang telah disusun untuk tahun 2013. Tetapi ketika masuk ke tahuntahun berikutnya, pola inkonsistensi atau bahkan kontradiktif masih terjadi. Sehingga perlu adanya pemecahan masalah baik dari segi paradigma, manajemen tindakan, hingga kebiasaan yang perlu diperbaiki. Berdasarkan data dari berbagai penelitian, 
ternyata tidak hanya di UNS yang mengalami kendala pelaksanaan program ini, terdapat juga di beberapa perguruan tinggi yang lain. Hanya saja, sebagai contoh kasus, di penelitian ini perguruan tinggi yang digunakan sebagai objek penelitian adalah Universitas Sebelas Maret (UNS). Dari latar belakang masalah tersebut maka tulisan ini akan difokuskan untuk menjawab persoalan tentang peran pertama serta utama dalam menyukseskan program green campus di perguruan tinggi, dinamika pelaksanaan program green campus di UNS, dan solusi lebih lanjut yang perlu diterapkan untuk mengatasi kekurangan pada dinamika pelaksanaan yang ada.

\section{Metode}

Penelitian ini merupakan penelitian kualitatif dengan pendekatan deskriptif. Bogdan dan Taylor (L.J. Maleong, 2011:4) menjelaskan bahwa metode penelitian kualitatif adalah sebuah prosedur penelitian yang hasilnya berupa data deskriptif berbentuk kata-kata tertulis dan lisan dari orang-orang dan perilaku yang diamati. Sedangkan menurut Syaodih Nana (2007:60), penelitian kualitatif dengan pendekatan deskriptif adalah cara untuk menganalisis serta mendeskripsikan fenomena, peristiwa, serta aktivitas sosial secara individu maupun kelompok. Data dalam penelitian ini adalah data primer dan sekunder. Subjek dalam penelitian ini yaitu tim pelaksana pemeringkatan UI Green
Sebelas Maret (UNS) Tahun 2020 karena peneliti ingin mengambil contoh yang ada di UNS. Data primer diperoleh melalui observasi, wawancara secara langsung, serta Focus Group Discussion (FGD) bersama Tenaga Pendidik Tim UIGC UNS yaitu Bapak Puguh Karyanto, S.Si., M.Si., Ph.D. Sedangkan data sekunder diperoleh dari dokumen Unit UIGC itu sendiri di laman webiste Green Campus UNS. Dokumen tersebut terdiri dari Rencana Strategis Pengembangan UNS Green Campus 2013 - 2020; Blue Print Pengembangan Green Campus 2013 - 2020; Peraturan Rektor UNS tentang Green Campus; Keputusan Rektor UNS tentang Tim Pengelola UIGC UNS; Surat Edaran Rektorat yang berhubungan dengan kebijakan Green Campus; serta Instruksi Rektor tentang dimensi-dimensi indikator Green Campus. Pengumpulan data dilakukan dengan beberapa metode, yaitu:

1. Wawancara yang dilakukan yaitu secara daring melalui platform media Zoom Clouds Meeting kepada Tenaga Pendidik Tim UIGC UNS yaitu Bapak Puguh Karyanto, S.Si., M.Si., Ph.D. dengan memberikan pertanyaanpertanyaan yang disusun secara tidak terstruktur (unstructure) dan bersifat terbuka (openended) yang dirancang untuk memunculkan pandangan dan opini dari partisipan. Adapun informan dipilih menggunakan teknik purposive sampling.

\section{Metric World University Ranking Universitas}


2. Focus Group Discussion (FGD) adalah teknik pengumpulan data yang umumnya dilakukan pada penelitian kualitatif dengan menghadirkan beberapa orang yang telah ditentukan kemudian membedah makna sebuah tema menurut pemahaman kelompok dalam forum FGD tersebut. Metode FGD memiliki ciri khas yang tidak dimiliki oleh metode riset kualitatif lainnya yaitu berupa interaksi antara peneliti dengan informan serta informan dengan informan lainnya. Pada sesi Focus Group Discussion (FGD) kali ini peneliti beserta informan lainnya melakukan diskusi mengenai pelaksanaan Program Green Campus UNS. FGD ini diadakan pada Sabtu, 10 Oktober 2020 bersama perwakilan mahasiswa UNS, Tim Greevo UNS, serta Tenaga Pendidik Tim UIGC UNS yaitu Bapak Puguh Karyanto, S.Si., M.Si., Ph.D.

3. Pengumpulan data dilakukan dengan observasi secara langsung ke lapangan untuk memperoleh informasi mengenai aktivitas sivitas akademika serta kondisi pelaksanaan program green campus di UNS yang berupa kekurangan mengenai implementasi program yang melatarbelakangi penelitian ini.

4. Studi dokumentasi digunakan untuk memperkuat data dalam penelitian berupa surat-surat resmi, rencana strategis pelaksanaan program (renstra), serta dokumen resmi lainnya yang menyangkut program green campus di UNS.

\section{Hasil dan Pembahasan}

\section{Peran Pimpinan Perguruan Tinggi dalam Menyukseskan Rencana Strategis Pengembangan Green Campus}

Berbagai gerakan berbentuk kampanye, penyuluhan, sosialisasi, maupun kegiatan fisik lainnya terus diupayakan oleh berbagai pemangku kebijakan di bangsa ini untuk mengurangi permasalahan lingkungan yang begitu kompleks. Tak terkecuali oleh perguruan tinggi yang sejak ditetapkannya UndangUndang Nomor 32 Tahun 2009 tentang Perlindungan dan Pengelolaan Lingkungan Hidup wajib mengintegrasikan upaya perlindungan dan pengelolaan lingkungan hidup ke dalam setiap kebijakan serta program yang dibentuk.

Program green campus merupakan program yang telah dilakukan baik oleh negara maju maupun berkembang guna mengurangi efek pemanasan global. Keberadaan program ini sangat diharapkan dapat menciptakan kesadaran masyarakat secara keseluruhan dalam berpartisipasi mengurangi pemanasan global. Pemerintah Indonesia kemudian mulai serius untuk melakukan perlindungan dan pengelolaan lingkungan hidup terhadap perguruan tinggi di Indonesia. Hal itu dimulai dengan penetapan 5 (lima) kampus sebagai perguruan tinggi percontohan untuk 
program green campus pada tahun 2013.

Standar green campus yang ada di Indonesia telah dikeluarkan oleh Universitas Indonesia di bawah pimpinan Prof. Riri Fitri Sari bernama UI GreenMetric. Standar ini digunakan sebagai sistem untuk pemeringkatan perguruan tinggi mengenai komitmen perguruan-perguruan tinggi dalam pengelolaan lingkungan hidup kampus. UI GreenMetric ini diluncurkan tahun 2010 dan pada 2017 telah diikuti oleh 515 perguruan tinggi dari 4 benua di dunia (Nurbaya dalam Buana, dkk, 2018). Di dalam kriteria penilaian UI GreenMetric ini terdapat 6 (enam) aspek sebagai berikut: (i) Setting and Infrastructure (SI); (ii) Energy and Climate Change (EC); (iii) Waste (WS); (iv) Water; (v) Transportation; dan (vi) Education.

Menurut Menteri Lingkungan Hidup Balthasar Kambuaya bahwa tujuan pelaksanaan pelaksanaan green campus ini untuk mengintegrasikan tridharma perguruan tinggi dalam melestarikan dan melindungi lingkungan hidup. Salah satu upaya Rektor UNS Surakarta Prof. Ravik Karsidi dalam menjaga kelestarian dan ekosistem adalah dengan melarang siapa pun dan dengan cara apa pun menangkap ikan dan burung yang ada di daerah kampus (Tempo.co, 2013). Di sini terlihat bahwa peran pimpinan perguruan tinggi cukup strategis dalam merealisasikan program kampus hijau.

Program green campus tidaklah mudah dalam mengimplementasikannya, perlu adanya manajemen yang baik dari pihak kampus, terutama dimulai dari pimpinan kampus itu sendiri. Pernah dilakukan penelitian di Universitas Katolik Parahyangan dan Institut Teknologi Nasional Bandung bahwa kendala terbesar yang dihadapi adalah mengenai lemahnya kebijakan pimpinan kampus serta tingkat pemahaman pengguna kampus yang masih rendah terkait konsep green campus ini (Puspadi, dkk, 2016). Sebagai faktor kekuatan, komitmen pengelola kampus dalam melaksanakan konsep green campus menjadi salah satu faktor penting. Sedangkan kurang optimalnya kebijakankebijakan yang dikeluarkan dan dikoordinasi dengan baik oleh pihak perguruan tinggi menjadi kelemahan tersendiri dalam pelaksanaan tersendiri dalam pelaksanaan program green campus.

Selain itu, melalui penelitian di beberapa universitas dan penelitian secara umum terkait green campus bahwa di Universitas Muhammadiyah Palangkaraya masih terdapat kendala mengenai lemahnya fungsi pengawasan soal implementasi konsep green islamic campus; Universitas Islam Indonesia terkait Kebijakan Kawasan Tanpa Rokok di Lingkungan masih belum adanya sanki yang tegas dari pimpinan perguruan tinggi; serta di penelitian secara umum kendalanya adalah kurang tegasnya peraturan, komitmen yang masih lemah dan mindset yang belum kuat (Buana, dkk, 2018). Oleh karena itu, di samping faktor-faktor lain, di 
sini posisi pimpinan perguruan tinggi dalam merealisasikan rencana program green campus menjadi strategis dan penting karena mempunyai peran dalam membentuk, menjalankan, mengawasi, sekaligus mengevaluasi jalannya program. program green campus semakin nyata. Program Jumat Sehat adalah program hari bebas emisi yang diwujudkan sekali setiap bulannya. Kampus menyediakan beberapa bus untuk kebutuhan transportasi di dalam lingkup universitas. Tidak ada yang boleh menggunakan kendaraan bermotor pribadi,

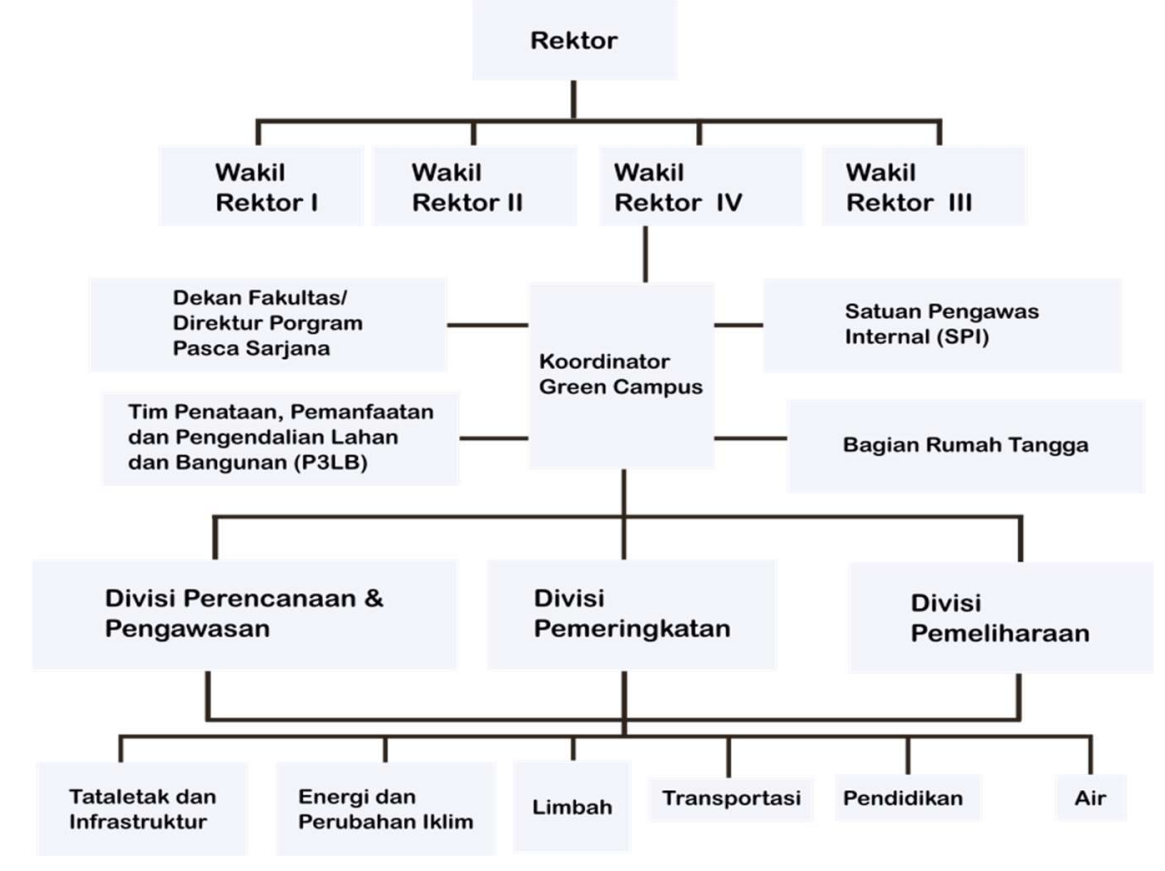

Gambar 2 .1 Struktur Organisasi Program Green Campus UNS (Renstra Green Campus UNS, 2013)

Berdasarkan data yang diberikan, hanya diperbolehkan menggunakan Universitas Sebelas Maret di tahun 2019 sepeda, bus kampus, atau jalan kaki. Hal ini hingga 2020 sudah mengalami kemajuan adalah salah satu wujud komitmen yang signifikan dalam implementasi kebijakan green campus. Struktur koordinasi (Gambar 1.1) yang bertanggung jawab terhadap program green campus sudah berjalan, hal ini ditunjukkan dengan kehadiran Wakil Rektor IV di setiap rapat mingguan sebagai koordinator langsung.

Selain itu, program Jumat Sehat yang diberlakukan setiap Jumat pertama tiap bulan di UNS menunjukkan realisasi ditunjukkan oleh pihak universitas terkait program green campus ini.

\section{Green Campus dan Dinamika Performa Pelaksanaan Program}

Terjadinya berbagai kasus lingkungan hidup, tidak akan bisa selesai jika terus dibiarkan, akan tetapi perlu dikaji terlebih dahulu aspek yang melatarbelakangi terjadinya hal tersebut. Tidak dipungkiri, terjadinya kasus lingkungan hidup di lingkup 
global, nasional, bahkan lokal sebagian besar berasal dari perilaku manusia yang tidak peduli, tidak bertanggung jawab, dan tidak konsisten terhadap komitmen yang telah dicanangkan. Salah satu faktor penting yang mempengarui perilaku masyarakat tersebut disebabkan cara pandang (paradigma) para pemangku kepentingan kemudian mempengaruhi implementasi kebijakan dan juga mempengaruhi sebagian perilaku sebagian besar masyarakat.

Dalam diskursus tentang etika lingkungan, terdapat dua teori yang menjadi perhatian utama yaitu antroposentrisme dan ekosentrisme. Dari dua teori besar tersebut, tampaknya antroposentrime sejauh ini masih menjadi dominan dalam pola pikir masyarakat mengenai etika lingkungan. Paradigma yang sering menjadi acuan, baik secara sengaja maupun tidak sengaja, oleh manusia dalam memandang alam semesta serta manusia itu sendiri yaitu paradigma antroposentrisme. Akibat cara pandang antroposentisme ini, manusia memandang bahwa ia adalah pusat dari alam semesta yang memiliki nilai, sedangkan alam dan segala isinya sekadar sebagai alat pemuas kepentingan dan kebutuhan hidup manusia (Sosial and Malang, n.d.). Karena itu, manusia dan kepentingannya dipandang sebagai nilai tertinggi di kehidupan ini. Manusia dianggap sebagai penguasa yang dapat dan boleh melakukan apa pun terhadap alam, termasuk melakukan eksploitasi terhadapnya karena alam dan lingkungan dianggap tidak memiliki nilai pada diri sendiri. Suatu kebijakan dalam kaitannya dengan lingkungan hidup yang dibuat manusia akan dianggap baik jika menguntungkan manusia, walaupun tidak menguntungkan bagi alam. Alam tidak menjadi pertimbangan moral atas perilaku manusia, segala kepentingan mengarah kepada manusia itu sendiri.

Argumen mengenai paradigma antroposentris ini sesungguhnya bersumber dari pandangan Aristoteles dalam bukunya The Politics. Dalam buku The Politics, Aristoteles jelas mengungkapkan bahwa tumbuhan disiapkan untuk kepentingan binatang dan binatang disediakan untuk kepentingan manusia (Aristoteles, 1986). Berdasarkan argumen ini, sah bagi manusia dalam memperlakukan ciptaan yang lebih rendah sesuai dengan kehendak dan keinginan dirinya dalam hal ini tumbuhan dan binatang secara kodrat dipandang lebih rendah dari manusia. Demikian sama halnya yang dinyatakan oleh Thomas Aquinas, Rene Descartes, dan Immanuel Kant dalam istilah the free and rational being bahwa manusia lebih terhormat dan tinggi dibandingkan dengan makhluk ciptaan lain, manusia adalah satu-satunya makhluk bebas dan rasional.

Sejalan dengan itu, Immanuel Kant berpandangan bahwa manusia merupakan makhluk rasional sedangkan makhluk lain adalah makhluk non-rasional. Oleh karena itu, manusia boleh dan sah secara moral untuk menggunakan makhluk non-rasional 
sebagai alat mencapai tujuan hidup manusia yaitu mencapai suatu tatanan dunia yang rasional. Rene Descartes lebih lanjut menegaskan bahwa manusia memiliki tempat istimewa di antara semua makhluk hidup di alam semesta. Manusia mempunyai jiwa yang memungkinkan untuk berpikir dan berkomunikasi menggunakan bahasa. Sedangkan binatang dan tumbuhan hanya memiliki tubuh yang tidak lebih dari sekadar mesin bergerak otomatis dan karena itu keduanya dipandang sebagai makhluk yang lebih rendah (Keraf, 2010). Dengan ini terlihat jelas bahwa etika barat ini sangat antroposentris, yang melihat tidak ada kekeliruan secara moral apapun bentuk perilaku manusia terhadap tumbuhan, binatang, serta makhluk hidup lainnya. Etika ini kemudian dituding sebagai sumber krisis ekologi sekarang ini, terkhusus menjadi sumber penyebab terjadinya kasus pengelolaan yang kurang baik pada program green campus.

Seperti yang telah dikemukakan di atas, berdasarkan data yang ditemukan, dalam hal ini UNS sudah mulai menunjukkan komitmen untuk menuju paradigma yang lebih baik terhadap lingkungan hidup yaitu ekosentrisme. Hal ini ditunjukkan sejak ditetapkannya UNS menjadi salah satu perguruan tinggi bersama 4 (empat) perguruan tinggi lainnya menjadi kampus percontohan kampus hijau, UNS mulai mencanangkan pelaksanaan green campus sebagai komitmen pimpinan dalam mewujudkan kampus yang ramah lingkungan dan berkelanjutan. UNS mengawali program green campus ini dengan terencana, terlihat pada metode penyusunan renstra green campus UNS 2013 (Renstra Green Campus UNS, 2013). Perencanaan program tersebut ditetapkan oleh Rektor UNS, Prof. Dr. Ravik Karsidi bersama dengan Menteri Lingkungan Hidup RI 2013, Prof. Dr. Balthazar Kambuaya, MBA. Susunan rensta program terdiri dari program, kegiatan, anggaran, prosedur pelaksanaan, hingga model evaluasinya. Telah ditetapkan juga Indikator Kinerja Utama (IKU) dan Indikator Kinerja Kegiatan (IKK) untuk mengukur keberhasilan program green campus. Penyusunan Renstra Green Campus UNS di tahun 20132015 yang menggunakan model alur kerja office of quality improvement dari University of Wisconsin Madison (dengan beberapa penyesuaian) dalam $A$ Collection of Planning Corner Articles disusun dengan sistematis dan ideal.

Selain itu, pengintegrasian program ke dalam renstra UNS membawa konsekuensi penyesuaian Rencana Pengembangan Jangka Panjang (RPJP) BLU UNS untuk tahun 2011 hingga 2013 dengan Blueprint Green Campus. RPJP BLU UNS tersebut berisi pentahapan lima tahun untuk tiap tahapnya. Pentahapan tersebut menggambarkan proses metamorfosa sistematis UNS menuju universitas bereputasi internasional dan unggul di dunia melalui salah satu program green campus. 
Bentuk struktur organisasi green adalah seperti masih banyaknya campus UNS pada gambar 1.1 yang dibentuk tahun 2013 terlihat sudah siap untuk menjalankan program green campus ini. Hal ini terbukti dengan hasil capaian kinerja berdasarkan program unggulan tahun 2013 menunjukkan hasil yang sesuai dengan target (dapat dilihat pada gambar 1.2). penggunaan bahan plastik sekali pakai di berbagai rapat kerja, kantin, dan kantor. Selain itu, ruang bebas rokok yang sekadar ditunjukkan melalui spanduk saja sehingga masih banyak ditemukan sivitas akademika yang merokok di tempat yang tidak semestinya. Beberapa perguruan tinggi lain seperti Itenas dan Unpar pun mengalami

\begin{tabular}{|l|l|c|c|}
\hline \multirow{2}{*}{ Program Unggulan } & \multicolumn{1}{|c|}{ Indikator Kinerja Kegiatan } & \multicolumn{2}{|c|}{ Kinerja } \\
\cline { 2 - 4 } & Target 2013 & Capaian 2013 \\
\hline \multirow{2}{*}{$\begin{array}{l}\text { 1. Keunggulan dalam } \\
\text { Riset }\end{array}$} & $\begin{array}{l}\text { a. Jumlah riset lingkungan unggulan (judul) } \\
\text { b. Angka partisipasi dosen dalam penelitian } \\
\text { bertema lingkungan }\end{array}$ & 800 & 750 \\
\cline { 2 - 4 } & $\begin{array}{l}\text { C. Jumlah publikasi bertema lingkungan di jurnal } \\
\text { nasional terakreditasi }\end{array}$ & 25 & 41 \\
\cline { 2 - 4 } & $\begin{array}{l}\text { d. Jumlah publikasi bertema lingkungan dalam } \\
\text { seminar nasional }\end{array}$ & 25 & 25 \\
\cline { 2 - 4 } & $\begin{array}{l}\text { f. Jumlah kerjasama penelitian lingkungan } \\
\text { f. Jumlah publikasi bertema lingkungan dalam } \\
\text { seminar internasional }\end{array}$ & $10 \%$ & $11,84 \%$ \\
\cline { 2 - 4 } & $\begin{array}{l}\text { g. Prosentase jurnal internasional bertema } \\
\text { lingkungan dan keberlanjutan dengan } \\
\text { keseluruhan jurnal }\end{array}$ & 10 & $\begin{array}{c}\text { Belum } \\
\text { terdata }\end{array}$ \\
\hline $\begin{array}{l}\text { 2. Keunggulan dalam } \\
\text { transfer dan } \\
\text { Pengembangan } \\
\text { Ilmu Pengetahuan }\end{array}$ & $\begin{array}{l}\text { Jumlah produk inovatif bertema lingkungan untuk } \\
\text { dipasarkan (mobil listrik dan fotofoltaic) }\end{array}$ & 2 & 2 \\
\hline $\begin{array}{l}\text { 3. Keunggulan dalam } \\
\text { Manajemen } \\
\text { Pengetahuan }\end{array}$ & a. Aplikasi situs green campus dalam web & 1 & 1 \\
\hline
\end{tabular}

\begin{tabular}{|c|c|c|c|}
\hline \multirow{2}{*}{ Program Unggulan } & \multirow{2}{*}{ Indikator Kinerja Kegiatan } & \multicolumn{2}{|c|}{ Kinerja } \\
\hline & & Target 2013 & Capaian 2013 \\
\hline \multirow{15}{*}{$\begin{array}{l}\text { 4. Keunggulan } \\
\text { dalam } \\
\text { Internasionalisa } \\
\text { si dan } \\
\text { Pencitraan } \\
\text { Publik }\end{array}$} & $\begin{array}{l}\text { a. Peringkat UI Green Metric (Masih menunggu } \\
\text { pengumuman dari UI) }\end{array}$ & 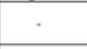 & 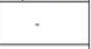 \\
\hline & $\begin{array}{l}\text { b. Jumlah layanan yang mendukung program green } \\
\text { campus }\end{array}$ & 2 & 2 \\
\hline & c. Jumlah kerjasama institusi dalam negeri & 1 & 1 \\
\hline & $\begin{array}{l}\text { d.Jumlah fasilitas pendukung green campus: } \\
\text { - Jumlah kolam penampung air hujan }\end{array}$ & 2 & 2 \\
\hline & - Jumlah sumur resapan & 32 & 32 \\
\hline & $\begin{array}{l}\text { - Jumlah penggantian bola lampu lama } \\
\text { dengan bola lampu yang hemat energi di } \\
\text { Gedung Rektorat UNS }\end{array}$ & 100 & 100 \\
\hline & $\begin{array}{l}\text { - Jumlah penggantian kran air lama dengan } \\
\text { kran air dengan fitur autostop di Gedung } \\
\text { Rektorat UNS }\end{array}$ & 20 & 20 \\
\hline & - Jumlah IPAL & 5 & 5 \\
\hline & - Jumlah IPAL Terpadu (DED) & 1 & 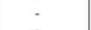 \\
\hline & - Jumlah unit pengomposan & $\begin{array}{c}2 \\
2800 \mathrm{~m}^{2}\end{array}$ & $\begin{array}{c}1 \\
1500 \mathrm{~m}^{2}\end{array}$ \\
\hline & - Jumlah (luas) pedestrian (trotoar) & $(1.770 \mathrm{~m})$ & \\
\hline & $\begin{array}{l}\text { - Jumlah produk penelitian yang dapat } \\
\text { diaplikasikan: }\end{array}$ & & 2 \\
\hline & \% Mobil listrik & 1 & 1 \\
\hline & $\therefore$ Unit Fotofoltaic & 1 & 1 \\
\hline & $\begin{array}{l}\text { Jumlah Kegiatan sosialisasi green campus di unit } \\
\text { kerja dan fakultas di UNS }\end{array}$ & 10 & 11 \\
\hline
\end{tabular}

Gambar 2 .2 Capaian Kinerja Kegiatan Unggulan Green Campus UNS Tahun 2013

Namun kondisi pencapaian yang baik tersebut tidak sepenuhnya berjalan dengan konsisten, terlihat pada tahun 2019 beberapa bagian struktur baru dapat berjalan seperti keterlibatan Wakil Rektor IV sebagai koordinator langsung di rapat-rapat rutin. Hal ini menunjukkan bahwa sempat ada ketidakberjalanan struktur dan pengelolaan program. Beberapa hasil pilot test juga baru terlihat, misalnya pilot test pada pembangunan ruang parkir vertikal di Gedung Pascasarjana UNS dan penyediaan jalur khusus sepeda. Sedangkan implementasi program green campus di UNS yang sekarang masih menunjukkan pelaksanaan yang kontradiktif persoalan yang tidak jauh berbeda seperti kurangnya sarana dan prasarana yang mendukung penerapan konsep green campus, tingkat pemahaman pengguna kampus yang masih rendah, dan lemahnya kebijakan pimpinan di program kampus hijau ini (Puspadi, dkk, 2016).

Dari sini kemudian dapat terlihat bahwa sebenarnya rencana strategis yang telah dibentuk secara sistematis tidak sepenuhnya akan berjalan mulus. Pola inkonsistensi dalam implementasi kebijakan masih terlihat, terutama terkait dengan paradigma, perilaku, dan komitmen bersama sebagai pondasi mendasar dalam mengimplementasikan kebijakan. 


\section{Konsistensi Paradigma, Manajemen} Tindakan, hingga Menciptakan Kebiasaan sebagai Alat Kesuksesan Program Green Campus

Terus menerus berpikiran antroposentrisme jelas bukan hal yang baik bagi kelangsungan lingkungan hidup. Bagaimanapun lingkungan hidup perlu menjadi prioritas di tengah-tengah modernitas yang diasumsikan lebih tidak ramah terhadap lingkungan dibanding gayagaya hidup lama (primitif). Gaya hidup yang memprioritaskan lingkungan hidup di atas segalanya memang tidak mudah digunakan di masa sekarang, namun keseimbangan hidup bagi segala unit alam semesta juga adalah tujuan yang harus dicapai bersama demi hidup yang berkelanjutan. Bagaimanapun penanganan lingkungan hidup, terkusus dalam program green campus, perlu prioritas tersendiri supaya setidaknya dalam lingkup kampus supaya bisa menjadi contoh terhadap penanganan lingkungan hidup di kawasan yang lain. Namun, problem inkonsistensi yang telah dipaparkan di atas bukan berarti bisa dijustifikasi. Inkonsistensi yang bersumber karena pola pikir yang terkadang masih melenceng ini mau tidak mau harus diubah sehingga pelaksanaan program green campus dapat terkelola dengan baik dan tidak menjadi kontradiktif di kampus hijau.

Jika dalam pembahasan sebelumnya telah dibahas tentang bagaimana pola pelaksanaan program green campus yang dilakukan oleh perguruan tinggi di
Indonesia, dalam hal ini peneliti mengambil contoh di Universitas Sebelas Maret (UNS), maka di pembahasan berikutnya ini akan lebih diarahkan pada bagaimana pengelolaan dilakukan dengan terlebih dahulu mematangkan pola pikir yang benar. Sehingga keberjalanan program akan sesuai dengan rancangan yang telah disusun.

Meminjam hasil pemetaan yang dilakukan oleh Seyyed Mohsen Miri dalam bukunya Menanam Sebelum Kiamat, ada dua pendekatan yang sepantasnya dipakai untuk mengatasi krisis lingkungan, yaitu: pertama, pemecahan dilakukan dengan pertimbangan atas segala sesuatu yang terlihat, yang sedang berlangsung, dan kemudian membuat perubahan jangka pendek serta merencanakan ulang. Namun bagi Seyyed, solusi yang pertama tidak begitu berpengaruh nyata, jika hanya berpegang pada solusi tersebut maka krisis dan permasalahan akan muncul kembali (Ridwanuddin, 2017). Solusi yang lebih realistis yaitu: kedua, pemecahan krisis harus dilakukan dengan menjabarkan sebab dan faktor munculnya krisis (aspek ontologis); memakai dasar keilmuan (aspek epistemologis); kerangka rohani, intelektual, serta paradigma budaya yang menyebabkan krisis terjadi dengan tetap mengacu pada pendekatan pertama di atas. Paradigma menurut Seyyed adalah bagian penting dan lebih realistis dengan tetap mengacu pada pertimbangan, perubahan jangka pendek, serta perencanaan ulang

Manajemen Paradigma dan Perilaku: Upaya Bergerak Menuju Kemajuan Pelaksanaan

Program Green Campus | Raditia Yoke Pratama, Shintia Nur Kartini dan Danisa Kusuma 
melalui evaluasi yang dilakukan.

Albert Schweitzer, pemenang Nobel tahun 1952 untuk bidang perdamaian dan ajaran filosofinya tentang "Reverence for Life" kemudian meluruskan paradigma yang seharusnya dipakai yaitu mengenai biosentrisme. la berpedoman bahwa "saya menjalani kehidupan yang menginginkan tetap hidup, di tengah kehidupan yang menginginkan untuk tetap hidup." (Schweitzer, 1964) Paul Taylor sebagai pendukung paradigma biosentrisme kemudian berpendapat bahwa biosentrisme didasarkan pada empat hal, yaitu:

a. Keyakinan bahwa manusia, hewan, tumbuhan berada pada kerangka yang sama serta anggota sejajar dalam komunitas kehidupan di bumi;

b. Keyakinan bahwa spesies manusia, hewan, dan tumbuhan adalah bagian dari sistem yang saling tergantung;

c. Keyakinan bahwa semua organisme adalah pusat kehidupan yang memiliki tujuan hidup sendiri;

d. Keyakinan bahwa manusia tidak lebih unggul dari makhluk hidup yang lain (Paul, 1986).

Dengan keyakinan dan paradigma biosentrisme tersebut maka akan mendorong manusia untuk lebih memerhatikan kondisi kepentingan lingkungan hidup secara serius. Selain itu, manusia juga memiliki kewajiban dan tanggung jawab moral atas keberadaan semua organisme, makhluk hidup, serta manusia memiliki ketergantungan terhadap benda-benda abiotik.

Di samping itu, Arne Naess memaparkan sebuah pandangan yang berkaitan erat dengan biosentrisme yaitu Deep Ecology. Filsuf asal Norwegia ini menjelaskan bahwa pandangan tersebut adalah suatu etika baru yang tidak berpusat pada manusia, ia berpusat pada makhluk hidup keseluruhan guna mengatasi persoalan lingkunga hidup. Lebih jauh, Arne Naess mengatakan bahwa deep ecology harusnya menjadi sebuah gaya hidup dan gerakan dari komunitas untuk menghasilkan solusi nyata terhadap lingkungan hidup. Deep ecology ini memiliki filsafat kearifan rumah tangga atau dikenal dengan filsafat ecosophy. Filsafat ini meliputi sebuah ilmu (science) yang bergeser menjadi sebuah kearifan (wisdom) berupa cara hidup dan pola hidup yang selaras dengan alam. Perubahan gaya hidup serta paradigma ini sangat ditekankan oleh Naess karena keresahannya terhadap krisis ekologi yang dialami saat-saat ini. la mengritik para ekonom yang beranggapan bahwa ekonomi sebagai segala-galanya dan bukan merupakan bagian dari kehidupan yang kaya ini. Naess melihat ada kesalahan reduksionistis yang mereduksi kehidupan manusia dan maknanya hanya sebatas makna ekonomis saja. Pertumbuhan ekonomi adalah satu hal utama yang harus dikejar, ini kesalahan fatal. Gerakan Naess ini dikenal sebagai sebuah gerakan filsafat lingkungan hidup.

Setelah berbicara terkait paradigma 
yang harus dianut bagi stakeholder maka langkah berikutnya adalah memastikan manajemen perilaku serta kebiasaan tindakan yang terbentuk selaras dengan paradigma. Ajzen memberikan gambaran terkait perilaku direncanakan yang dapat digunakan untuk memprediksi apakah seseorang akan menjalankan atau tidak menjalankan suatu perilaku (Mahyarni 2013). Gambaran dari Ajzen ini dikenal dengan teori perilaku direncanakan (theory of planned behaviour). Teori yang merupakan berangkat dari kajian psiokologi sosial ini menggunakan tiga konstruksi sebagai anteseden dari intensi menuju perilaku. Tiga konstruksi tersebut adalah behavioral beliefs, normative beliefs, dan control beliefs. Behavioral beliefs menghubungkan suatu perilaku dengan berbagai manfaat atau kerugian yang mungkin diperoleh jika melakukan atau tidak melakukan suatu perilaku; normative beliefs adalah keyakinan untuk berperilaku yang dipengaruhi oleh pandangan orang-orang lain terhadap dirinya; sedangkan control beliefs cenderung tergantung kepada situasi dan jenis perilaku yang dilakukan. Menurut teori ini, intensi adalah kombinasi dari ketiga konsep tersebut. Intensi menjadi penentu terpenting bagi perilaku seseorang. Konsep-konsep ini dapat digunakan untuk membangun kesadaran serta menciptakan kebiasaan mengenai perilaku yang harus digunakan dalam menjalankan program green campus.

Di samping itu, keyakinan yang kuat terhadap ketersediaan sumber daya serta kesempatan yang dimiliki individu sangat mempengaruhi persepsi kontrol individu terhadap perilaku. Tingginya persepsi kontrol diri individu akan semakin membuat keberhasilan bisa tercapai dan kesulitan dapat teratasi. Sedangkan di lain sisi, teori Parsons mengenai action theory juga berhubungan erat dengan teori perilaku direncanakan. Inti dari action theory tersebut adalah tindakan itu diarahkan pada suatu tujuan; tindakan terjadi di dalam suatu situasi tertentu dimana ada elemen yang sudah pasti dan elemen yang digunakan sebagai alat untuk mencapai tujuan; serta tindakan itu diatur sehubungan dengan penentuan alat dan tujuan (Johnson, 1986). Teori mengenai perilaku direncanakan ini terbukti pada penelitian yang dilakukan oleh (Ryua, dkk,2003) terkait dengan keinginan dokter untuk berbagi pengetahuan. Model theory of planned behaviour yang dikembangkan memiliki pengaruh yang kuat terhadap keinginan dokter untuk berbagi pengetahuan baik secara langsung atau tidak langsung. Perilaku yang dirasakan mempunyai efek terhadap preferensi untuk berbagi pengetahuan dibanding dengan norma-norma subjektif atau sikap. Sikap sendiri menjadi faktor penting kedua setelah perilaku (Mahyarni, 2013). Ini kemudian menjadi penting dan cukup menjadi dasar bahwa teori ini perlu dimasukkan pada proses implementasi suatu program, dalam hal ini adalah green campus. Efeknya 
adalah untuk mengidentifikasi bagaimana dan kemana strategi dibentuk mengenai perubahan perilaku dan menjelaskan aspek penting terhadap faktor perilaku-perilaku manusia. Maka dari itu, mengingat kekurangan yang terjadi dalam implementasi program green campus adalah seperti kurang adanya pemahaman masyarakat kampus, kurang tegasnya peraturan, komitmen yang masih lemah dan mindset yang belum kuat sehingga perlunya strategi yang dikaitkan dan dikaji dengan paradigma lingkungan, faktor perilaku masyarakatnya, serta kemampuan sumber daya yang ada.

\section{Simpulan}

Menjaga lingkungan hidup telah menjadi tantangan tersendiri bagi pemangku kepentingan di zaman sekarang. Kompleksnya permasalahan lingkungan yang dihadapi menghasilkan berbagai program untuk menuntaskan permasalahan tersebut. $\mathrm{Di}$ antara permasalahannya adalah seperti semakin menipisnya sumberdaya alam tak terbaharui, meningkatnya emisi gas rumah kaca, pencemaran air dan udara, penurunan daya dukung dan daya tampung lingkungan, banjir, longsor, kekeringan, sampai degradasi keanekaragaman hayati. Maka dari itu, green campus hadir sebagai salah satu solusi terkait lingkungan hidup di lingkup perguruan tinggi.

Dengan mengambil contoh pelaksanaan program green campus di
UNS, kendala pelaksanaan program ini ternyata juga ditemui di beberapa perguruan tinggi yang lain. Fokus penelitian ini adalah menjawab pertanyaan: (1) siapa yang memiliki peran pertama serta utama dalam menyukseskan program green campus di perguruan tinggi; (2) dengan mengambil contoh pelaksanaan di UNS, bagaimana dinamika pelaksanaan program green campus selama ini; (3) lalu apa solusi lebih lanjut yang perlu diterapkan untuk mengatasi kekurangan pada dinamika pelaksanaan yang ada.

Subjek yang diambil di penelitian ini adalah Bapak Puguh Karyanto, S.Si., M.Si., Ph.D sebagai Tenaga Pendidik Tim UIGC UNS. Hasil dan pembahasannya adalah bahwa: pertama, program green campus tidaklah mudah dalam mengimplementasikannya, perlu adanya manajemen yang baik dari pihak kampus, terutama dimulai dari pimpinan kampus itu sendiri. UNS sendiri sejak tahun 2019 menunjukkan perbaikan yang lebih baik, salah satunya pada bagian keberjalanan struktur, hal ini ditunjukkan dengan kehadiran Wakil Rektor IV di setiap rapat mingguan sebagai koordinator langsung.

Kedua, dalam diskursus tentang etika lingkungan, terdapat dua teori yang menjadi perhatian utama yaitu antroposentrisme dan ekosentrisme. Etika antroposentrisme kemudian dituding sebagai sumber krisis ekologi sekarang ini, terkhusus menjadi sumber penyebab terjadinya kasus pengelolaan yang kurang baik pada 
program green campus. Namun,

adalah kurang adanya pemahaman berdasarkan data yang ditemukan, dalam hal ini UNS sudah mulai menunjukkan komitmen untuk menuju paradigma yang lebih baik terhadap lingkungan hidup yaitu ekosentrisme. Namun kondisi pencapaian yang baik tersebut tidak sepenuhnya berjalan dengan konsisten, data menunjukkan pelaksanaan yang tidak sesuai atau bahkan kontradiktif masih bisa ditemukan hingga sekarang. Dari sini kemudian bisa diketahui bahwa pola inkonsistensi dalam implementasi kebijakan masih terlihat, terutama terkait dengan paradigma, perilaku, dan komitmen bersama sebagai pondasi mendasar dalam mengimplementasikan kebijakan.

Ketiga, inkonsistensi yang bersumber karena pola pikir yang terkadang masih melenceng ini mau tidak mau harus diubah sehingga pelaksanaan program green campus dapat terkelola dengan baik dan tidak menjadi kontradiktif di dalam program kampus hijau. Paradigma menurut Seyyed menjadi bagian penting dan lebih realistis dengan tetap mengacu pada pertimbangan, perubahan jangka pendek, serta perencanaan ulang melalui evaluasi yang dilakukan. Di samping itu, berhubungan dengan individu, keyakinan yang kuat terhadap ketersediaan sumber daya serta kesempatan yang dimiliki individu sangat mempengaruhi persepsi kontrol individu terhadap perilaku. Maka dari itu, mengingat kekurangan yang terjadi dalam implementasi program green campus masyarakat kampus, kurang tegasnya peraturan, komitmen yang masih lemah dan mindset yang belum kuat sehingga perlunya strategi yang dikaitkan dan dikaji dengan paradigma lingkungan, faktor perilaku masyarakatnya, serta kemampuan sumber daya yang ada.

\section{Ucapan Terima Kasih}

Terima kasih kepada: Tim Pelaksana Pemeringkatan UI Green Matric World University Ranking Universitas Sebelas Maret Surakarta (UNS) Tahun 2020 dan Bapak Puguh Karyanto, S. Si., M. Si., Ph.D.; Perwakilan mahasiswa saat Forum Group Discussion Green Campus pada 10 Oktober 2020; Greevo UNS; Tim Redaksi Jurnal Pendidikan Sosiologi Fakultas IImu Sosial UNY dan; Seluruh pihak yang telah membantu dalam penelitian ini.

\section{Daftar Pustaka}

Aristoteles. (1986). The Polilitcs. Middlesex: Penguin Books.

Buana, R. P., Mia, W., \& Rindu, E. (2018). "Pengembangan Indikator Peran Serta Pihak Manajemen Perguruan Tinggi Dalam Penerapan Konsep Green Campus." RekaRacana: Jurnal Teknil Sipil, Volume 4, No 4, 2018, 8293.

Johnson, Doyle Paul di indonesiakan oleh Robert M. Z Lawang. (1986). "Teori Sosiologi : Klasik Modern Jilid II". Jakarta : PT. Gramedia Pustaka Utama.

Keraf, A. Sonny. (2006). Etika Lingkungan Hidup. Jakarta: Kompas.

Keraf, A. Sonny. (2010). Etika Lingkungan Hidup. Jakarta: Kompas.

Manajemen Paradigma dan Perilaku: Upaya Bergerak Menuju Kemajuan Pelaksanaan

Program Green Campus | Raditia Yoke Pratama, Shintia Nur Kartini dan Danisa Kusuma Mardani 
Mahyarni, Mahyarni. (2013). "Theory Of Reasoned Action and Theory Of Planned Behavior (Sebuah Kajian Historis Tentang Perilaku)." Jurnal ELRIYASAH, Volume 4, No 1, 2013, 13.

Maleong, L.J. (2011). "Metodologi Penelitian Kualitatif Edisi Revisi". Bandung: PT Remaja Rosdakarya.

Puspadi, N.A., Mia, W., \& M., Rangga S. (2016). "Perbandingan Kendala Dan Tantangan Penerapan Konsep Green Campus Di Itenas Dan Unpar." Jurnal Onlile Teknik Sipil Institut Teknologi Nasional Bandung, Volume 2, No 2, 2016, 23-35.

Rencana Strategis Bisnis Program Green Campus UNS, (2013). https://greencampus.uns.ac.id/legalbasis/. Diunduh pada 21 Oktober 2020.

Ridwanuddin, Parid. (2017)."Ekoteologi dalam Pemikiran Badiuzzaman Said Nursi". Jurnal Lentera, Volume 1, 2017, 39.

Ryua, Seewon., Seung, H., \& Ingoo, H. (2003). "Knowledge Sharing Behaviour of Physicians in Hospitals." Expert Systems with Applications, Volume 25, No 1, 2003, 113-22.

Secretariat General National Energy Council. (2019). "Indonesia Energy Outlook 2019". ISSN 25273000. https://www.esdm.go.id/en/publicatio n/indonesia-energy-outlook. Diunduh pada 23 Oktober 2020.

Sukmadinata, Nana Syaodih. (2013). "Metode Penelitian Pendidikan". Bandung: PT. Remaja Rosdakarya.

Sutoyo. (2013) "Paradigma Perlindungan Lingkungan Hidup." Jurnal Hukum, Volume 4, No 1, 2013.

Tempo.co. (2013). "5 Perguruan Tinggi Jadi Percontohan Kampus Hijau". https://nasional.tempo.co/read/46547 8/5-perguruan-tinggi-jadipercontohan-kampushijau/full\&view=ok. Diunduh pada 21 Oktober 2020.

Taylor, Paul. (1986). "Respect for Nature: A Theory of Environmental Ethicts" (Princeton: Princeton Univ. Press), hlm. 13. Ibid. hlm. 53. 